\title{
Research Progress on Reference Genes of Insect for Quantitative Real-time Reverse Transcription PCR (RT-qPCR)
}

\author{
Cai-hua Shi ${ }^{1, *}$, Jing-rong Hu${ }^{1}$, You-jun Zhang ${ }^{1,2}$ \\ ${ }^{1}$ College of Agriculture, Yangtze University, China \\ ${ }^{2}$ Department of Plant Protection, Institute of Vegetables and Flowers, Chinese Academy of Agricultural Science, China
}

Copyright (C) 2015 by authors, all rights reserved. Authors agree that this article remains permanently open access under the terms of the Creative Commons Attribution License 4.0 International License

\begin{abstract}
Quantitative real-time reverse transcription PCR (RT-qPCR) has become the most important method for the quantification of mRNA transcription levels owing to its, specificity, sensitivity, reproducibility, and efficiency. In order to avoid sample-to-sample and run-to-run variations particularly in RNA extraction, RNA quality and cDNA reverse transcription level, etc. it is necessary to use housekeeping gene which stably expressing as reference gene. Ideally, the housekeeping gene should not be regulated or influenced by the experimental procedure or co-regulated with the target gene. Studies insect models have shown that the expression levels of commonly used reference genes can differ among different tissue, organ types or physiological conditions. However, improper selection of reference genes will result in inaccurate calculation results and consequently obscure actual biological differences among samples, even opposite conclusion. Therefore, reference genes which specific stably expression in each experimental system should be selected in different insects and different experiments. This review aims to provide research achievements of domestic and foreign scholars on insect reference genes, which provide great promise for the future.
\end{abstract}

Keywords Reference Gene, Insect, RT-qPCR, Progress

\section{Introduction}

Quantitative real-time reverse transcription PCR (RT-qPCR) is invented by Applied Biosystems company in the United States in 1996, has become the most important method for the quantification of mRNA transcription levels owing to its, specificity, sensitivity, reproducibility, and efficiency. RT-qPCR has turned into a technique extensively employed for quantification of mRNA transcripts. Especially for studying the expression of small set of genes, or no use Northern blot, can be used to complement the above mentioned methods[1].For this reason, RT-qPCR has been widely used in the expression profiling of selected genes in biological research.

RT-qPCR is divided into absolute quantification and relative quantification. Relative quantification methods depend on reference genes for normalization. However, RT-qPCR measures the mRNA transcript levels differentially contributed by specific biological conditions as well as confounding factors that are non-specific to the biological conditions and non-reproducible in different experiments. Even with careful control of technical variables[2,3], confounding factors may still result from sample-to-sample and run-to-run variations particularly in RNA extraction, RNA quality and cDNA reverse transcription level ,etc. Data normalization using internal reference genes in thus a crucial step necessary to minimize the influence of confounding factors and improve the fidelity of the quantification process with respect to the specific biological conditions[4].Internal reference genes are usually chosen from "housekeeping" genes with abundant and stable expression under various experimental conditions $[5,6]$.

Ideally, the housekeeping gene should not be regulated or influenced by the experimental procedure or co-regulated with the target gene. The housekeeping gene should also be expressed in abundance and have minimal innate variability. Studies insect models have shown that the expression levels of commonly used reference genes can differ among different tissue, organ types or physiological conditions $[7,8]$. However, improper selection of reference genes will result in inaccurate calculation results and consequently obscure actual biological differences among samples, even opposite conclusion [9]. Gutierrez [10] etc. has shown that incorrect or improper internal reference genes may result in gene expression level in the deviation of 100 times. For this reason, it is very important to select proper internal reference genes.

In current, a few insect's reference genes have been validated and published with RT-qPCR and gene chips used[11]. Aim of the paper is to sum up the reference genes about insect among different tissues, cells and deal with factors, is to provide theoretical reference basis for studying on other insects. 
Table 1. Commonly used reference genes for insects

\begin{tabular}{ccc}
\hline Gene symbol & Full gene name & (putative) Function \\
\hline$\beta$-actin & Beta actin & $\begin{array}{c}\text { Involved in cell motility, structure and } \\
\text { integrity } \\
\text { Glycolytic enzyme }\end{array}$ \\
GAPDH & Glyceraldehyde-3-phosphate dehydrogenase & Structural constituent of ribosome \\
18 S rRNA & 18S ribosomal RNA & Protein involved in exocytosis \\
Stx16 & Syntaxin 16 & translation of a subset of cellular \\
transcripts
\end{tabular}

\section{Selection of Reference Genes for Insects}

When studying gene expression patterns in different tissues, a commonly used reference gene may be not stable under all experimental conditions[12]. Therefore, the expression levels of commonly used reference genes can differ among different tissue/organ types or physiological conditions. Ideally, the reference gene should not be false gene, should be expressed in abundance and have minimal innate variability, $\mathrm{Ct}$ value of the reference gene should be between 15 to 30 [13,14]. In current, a few commonly used reference genes in insects such as: EF1-a (elongation factor-1 alpha), GAPDH (glyceraldehyde-3-phosphate dehydrogenase), SDHA (succinate dehydrogenase complex subunit A) and so on[15], have relatively stable expression level in cell metabolism (Table 1).

Each candidate reference gene should be evaluated under specific experimental conditions for gene expression profiling to make sure expression occurs at a constant level. Furthermore, researchers have documented ,to improve robustness of the experiment, it is recommended to use more than one reference genes and to verify that their transcriptional activity are stable across conditions and tissue types.

\section{Research of Reference Genes for Insects}

Although reference genes commonly have been as the standard of goal genes, a large number of studies have shown that any kind of "housekeeping gene" expresses constantly only on a special condition. The reference genes at the same treat factor may be different because of their species difference. The reference genes at the same species may also be different because of different experiment condition. At present, the study on reference genes as follows:

Li-hua Chen[16] et al. evaluated four genes in different organs and developmental stages of Philosamia Cynthia ricini and identified that the best reference gene varied according to the tissue and physiological condition, $\beta$-actin in blood, fat body, midgut, silk gland and larvae, pupae, adult, egg of eri-silkworm was more stable as a suitable reference gene.

Miao Yuan[17] evaluated eight candidate genes of Nilaparvata lugens, RPS15, TUB, 18S, and EF should be required for a suitable normalization in the different developmental stages; RPS11, 18S, and RPS15 in the different body parts;RPS11,EF, and RPS15 in the two different geographic populations; RPS15, TUB, and EF in the different temperature treatment samples; RPS11,EF, and TUB in the pesticide-stressed samples; RPS 15,TUB,EF, and RPS11 in the different diets treatments; RPS11, AK, and EF in the starvation treatments.

Sun[18] et al. evaluated eight commonly used candidate genes of Tetranychus cinnabarinus, RPS18 and 5.8SrRNA had the most stable expression regardless of the four different strains, whereas RPS18 and $\alpha$-TUB were expressed most stably in different developmental stages.

Jia Wang[19] et al. evaluated ten candidate genes in different organs and developmental stages of Bactrocera 
minax , based on the comprehensive analysis of stability ranking, UBQ,GAPDH and GST were recommended as the reference genes for different developmental stages, and TUB, GAPDH and GST for different body parts of adults.

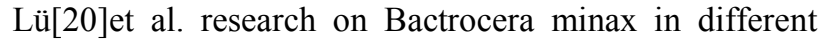
developmental stages, RPL 32 was expressed most stably as a suitable reference gene.

Liu-hao Wang[21] research on Bactrocera minax in different developmental stages, $\alpha$-TUB、RPL32and EF1- $\alpha$ were expressed most stably as a suitable reference gene.

Wang Song[22] et al. evaluated ten candidate genes in different survival time of Philosamia Cynthia ricini, RPS, GAPDH and $\alpha$-TUB were recommended as the most suitable reference genes.

Raman Bansal[23]et al. research on Aphis glycines in different developmental stages, TBP was expressed most stably as a suitable reference gene.

Chang-ning Guo[24] evaluated seven candidate genes of phyllonorycter Ringoniella, $\beta$-TUB and $\beta$-actin should be required for a suitable normalization in the different developmental stages; $\beta$-actin and $18 \mathrm{~S}$ in the different body parts; $\beta$-actin and $\beta$-TUB in the pesticide-stressed samples.

Su-ping $\mathrm{Xu}[25]$ evaluated six traditional (18SrRNA, ACTB,RPL3,PPI,TBP, RPII) and one novel (DIMT) candidate reference genes of Aphis gossypii Glover, PPI and DIMT were the most reliable reference genes in different morphs, hosts, and tissues; PPI, RPII and DIMT are suitable reference genes for different developmental stages samples.

Fang Chen[26]et al. evaluated six candidate reference genes ( $\alpha$-TUB,GAPDH,rpl32, $\beta$-TUB,SDHA and TBP) in different developmental stages of P.solenopsis under seven different temperature regimes by RT-qPCR method, $\alpha$-TUB can be used as a reference gene for the 2nd and 3rd instar nymph, and rpl32 could be used as the reference gene for female adult under different temperature regimes.

Niu[27] research on Panonychus citri(McGrego) by RT-qPCR method, RPII was expressed most stably in different developmental stages as a suitable reference gene; $\alpha$-TUB and RPII could be used as the reference gene under different temperature regimes. Niu[54], et al. research on the expression stability reference genes in different tissues of pesticide-susceptible and pesticide-exposed in Panonychus citri(McGrego). EF-1 $\alpha$ and GAPDH exhibited the most stable.

$\mathrm{Lu}[28]$ et al. evaluated candidate reference genes of Nilaparvata lugens, GAPDH and UCCR should be required for a suitable normalization in the different developmental stages; RPL10,AK and EF-1 $\alpha$ in the different body parts; RPL10 and EF-1 $\alpha$ in the different geographic populations; GAPDH and EF-1 $\alpha$ in the different temperature treatment samples.

Matthias[29] et al. have identified seven orthologs of commonly used housekeeping genes(actin, EF-1 $\alpha$, GAPDH, RP49, TubA1, UBI, and CG13220) in the desert locust, the most preferred reference genes were RP49,EF- $1 \alpha$ and ACT for studies of fifth instar nymphs; however, GAPDH, UBI and EF- $1 \alpha$ in adult brains.
TOUTGES[30] et al. researched on the candidate reference genes in T. castaneum, rps6,rpl13a, rps3, and rps18 were the most stably in different developmental stages as a suitable reference gene.

N.H.BAGNALL[31] et al. researched on the candidate reference genes in Lucilia cuprina, 18SrRNA, 28SrRNA, GST1, $\beta$-TUB and RPLPO were the most stably in different developmental stages as a suitable reference gene.

Mamidala[32] et al. research on the expression stability of eight reference genes in different tissues and developmental stages of pesticide-susceptible and pesticide-exposed in Cimex lectularius by using qRT-PCR.RPL18 exhibited the most stable gene expression across all the tissue and developmental-stage samples.

Zhang[33] et al. have identified twelve candidate reference genes of $\mathrm{H}$. armigera and evaluated for their expression stability under different biotic and abiotic conditions. The most suitable candidate combinations of reference genes were as follows: $28 \mathrm{~S}$ and RPS15 for developmental stages; RPS15 and RPL13 for larvae tissues; EF and RPL27 for adult tissues; GAPDH, RPL27, and $\beta$-TUB for nuclear polyhedrosis virus infection; RPS15 and RPL32 for insecticide treatment; RPS15 and RPL27 for temperature treatment; and RPL32, RPS15, and RPL27 for all samples.

Muhammad Shakeel[34] et al. evaluated the stability of expression of nine potential reference genes under different experimental conditions including temperature, mechanical injury, starvation, photoperiod, and developmental stages of Helicoverpa armigera, RPL28 and RPS15 were found to be the most stable reference genes in case of starved larvae, temperature stressed larvae, and different developmental stages. HSP90 and TUBB proved to be highly stable in case of photoperiod stressed larvae. TUBB and GAPDH were the most stable reference genes in case of larvae subjected to mechanical injury.

Cardoso[35] et al. evaluated the expression stability of six genes (Actin, Gapdh, Rp49, Rps17, $\alpha$-tubulin, and GstD1) among species within the same life stage and between life stages within each species of the Calliphoridae family. Actin, Gapdh, and Rp49 were the most stable among the selected genes.

Jia-hong $\mathrm{Wu}[36]$ et al. evaluated six housekeeping genes in Ae.albopictus, rspL40 and BTF3a has the most stable expression in different tissues, whereas rspL40 and rsp5 stably in different blood feeding phases.

Ran Peng[37] et al. detected seven commonly used reference genes (ACT,GAPDH, 28SrRNA, RPL3, a-Tubulin, UBC and TBP) in different development stages of Bombyx mori. ACT3, GAPDH and a-Tubulin in the mid-gut, $\alpha$-tubulin, UBC and TBP in the fat body as well as a-Tubulin, ACT3 and UBC in the Malpighian tubule were identified as the most stable genes.

Shen[38] et al. validated the suitable reference genes for gene expression profiling in different tissues of B. dorsalis. Moreover, appropriate reference genes were selected out for gene expression profiling of the same tissues taking the 
sexual differences into consideration. ACT2 and a-TUB are the best choice for both males and females in the midgut and Malpighian tubules. However, a-TUB and ACT1 are the best pair for fat body.

$\mathrm{Yu} \mathrm{Wu}[39]$ et al. detected the expression level of seven commonly used reference genes (Actin3, GAPDH, 28SrRNA, RPL3, $\alpha$-Tubulin, UBC and TBP) in Bombyx mori. $\alpha$-TUB and $28 \mathrm{~S}$ rRNA were the most stable expression in middle silkgland, GAPDH and 28SrRNA in rear silkgland, $\alpha$-TUB and UBC in fat body.

Rafaela[40] et al. evaluated the expression stability of five candidate reference genes (18S rRNA, GAPDH, b-actin, a-tubulin and ribosomal protein L26) in two tissues (salivary gland and intestine) and under different physiological conditions (before and after blood feeding and after infection with T. cruzi or T. rangeli) of Rhodnius prolixus. 18S rRNA, GAPDH and a-tubulin showed acceptable stability for studies in all of the tissues and experimental conditions evaluated. $\beta$-actin, one of the most widely used reference genes, was confirmed to be one of the most suitable reference genes in studies with salivary glands.

D. Majerowicz[41] et al. compared the expression of seven genes in organs of Rhodnius prolixus under diverse conditions, Rp18S and EF-1a were the most reliable genes for normalization, $\mathrm{Rp} 18 \mathrm{~S}$ was also the best reference gene in the fat bodies of unfed and fed insects. EF-1a was found to be the best reference gene for comparison between posterior midguts, and MIP or Actin should be used to compare gene expression in the ovaries.

Hornakova[42] et al. assessed the stability of eight reference genes in the labial gland and fat body of the bumblebees Bombus terrestris and Bombus lucorum of different ages. AK and PLA2 were the most stable genes in both tissues of B. terrestris. EF-1a and PLA2 were the most stable genes for the labial gland and fat body of B. lucorum.

Swapna Priya Rajarapu[43] et al. validated six A. planipennis reference genes (ACT; $\beta$-TUB, GAPDH; RPL7; EF-1 $\alpha$; and UBQ) in different larval tissues, developmental stages and two treatments. TEF- $1 \alpha$ is the most appropriate reference gene.

Ponton[44] et al. analyzed the expression levels of seven candidate reference genes (Actin, EF1, Mnf, Rps20, Rpl32, Tubulin and 18S) in Drosophila melanogaster that were injured, heat-stressed, or fed different diets. Actin, Mnf and TUB were the most stable genes in heat-stressed treatments, RPL32 and $\alpha$-TUB in fed different diets, ACT, TUB and EF-1 $\alpha$ in injured.

Scharlaken B[45] et al. analyzed the expression of eleven candidate reference genes in the honeybee head, for their potential use in the analysis of differential gene expression following bacterial challenge.actin,RPS18 and GAPDH were found suitable reference genes in the honeybee head in the context of bacterial infection.

Maroniche[46] et al. used reference genes ACT,TUB,GAPDH, EF-1 $\alpha$, RPS1 8 and UBI from Delphacodes kuscheli, UBI, followed by RPS18 and ACT, are the most suitable genes as internal controls for quantitative gene expression studies in MRCV-infective planthoppers.

Xue[47] et al.had found the use of 28S rRNA as a housekeeping gene in real-time quantitative PCR analysis of gene transcription in insect cells infected by viruses.

Jeffrey C. Lord[48] et al. evaluated reference genes expression in Tribolium castaneum exposed to Beauveria bassiana. The most stable were ribosomal protein genes, RPS3, RPS18, and RPL13a.

$\mathrm{Niu}[49]$ et al. evaluated the stability of five candidate internal reference genes: EF-1 $\alpha$, PPIA,RPL23, TBP and UBI, in relation to Israeli acute paralysis virus (IAPV) infection of Bombus terrestris. PPIA as the single, most-optimal internal reference gene and the combination of PPAI-RPL23-UBI as a fully-sufficient multiple internal reference genes set for IAPV infection experiments.

Jiang[50] et al. evaluated the stability of four candidate internal reference genes from Liposcelis bostrychophila, $18 \mathrm{~S}$ rRNA was the most stability for deltamethrin induction and the different developmental stages.

Katina [51] et al. tested six candidate reference genes for normalizing transcription levels of D. pulex genes. Xbp1, Tbp, CAPON and Stx16 were suitable reference genes for accurate normalization in qRT-PCR studies using Chaoborus-induced.

Marie-Pierre Chapuis[52] et al. assessed a suite of reverse transcription-quantitative PCR reference genes for analyses of density-dependent behavioural plasticity in the Australian plague locust, Arm and EF1a are the most stably expressed combination of two reference genes of the eight examined.

Wang[53] et al. chose ten genes as candidate reference genes in Mylabris cichorii L. (Coleoptera: Meloidae), recommended UBE3A and RPL22e as suitable reference genes in females and UBE3A, TAF5, and RPL22e in males.

To collected the results of previous scholars show that the reference genes at the same insect may be different because of different physiological conditions. The reference genes at the same physiological conditions or treat factor may also be different because of their species difference (Table 2). Therefore, the reference genes of stable expression absolutely in all conditions don't exist. To select suited reference genes for different experiment when we study different goal genes, can't blindly reference. 
Table 2. The reference genes of insects in different experiment conditions

\begin{tabular}{|c|c|c|c|c|c|c|c|c|c|c|}
\hline \multirow[b]{2}{*}{ Insect name } & \multicolumn{10}{|c|}{ Different treatment } \\
\hline & Organ & $\begin{array}{c}\text { Developmental } \\
\text { stage }\end{array}$ & $\begin{array}{l}\text { Geographic } \\
\text { population }\end{array}$ & Temperature & $\begin{array}{l}\text { Pesticide } \\
\text { stressed }\end{array}$ & $\begin{array}{c}\text { Diets } \\
\text { treatment }\end{array}$ & $\begin{array}{c}\text { Starvation } \\
\text { treatment }\end{array}$ & $\begin{array}{c}\text { Virus } \\
\text { infection }\end{array}$ & $\begin{array}{c}\text { Photoperiod } \\
\text { stressed }\end{array}$ & $\begin{array}{c}\text { Mechanical } \\
\text { injury }\end{array}$ \\
\hline $\begin{array}{l}\text { Philosamia } \\
\text { Cynthia ricini }\end{array}$ & $\beta$-actin & $\beta$-actin & - & - & - & - & - & - & - & - \\
\hline $\begin{array}{l}\text { Nilaparvata } \\
\text { lugens }\end{array}$ & $\begin{array}{c}\text { RPS11 } \\
\text { 18S rRNA } \\
\text { RPS15 }\end{array}$ & $\begin{array}{c}\text { RPS15 } \\
\text { TUB } \\
\text { 18S rRNA } \\
\text { EF }\end{array}$ & $\begin{array}{l}\text { RPS11 } \\
\text { EF-1a } \\
\text { RPS15 }\end{array}$ & $\begin{array}{l}\text { RPS15 } \\
\text { TUB } \\
\text { EF-1a }\end{array}$ & $\begin{array}{l}\text { RPS11 } \\
\text { EF-1a } \\
\text { TUB }\end{array}$ & $\begin{array}{l}\text { RPS } 15 \\
\text { TUB } \\
\text { EF-1a } \\
\text { RPS11 }\end{array}$ & $\begin{array}{c}\text { RPS11 } \\
\text { AK } \\
\text { EF-1a }\end{array}$ & - & - & - \\
\hline $\begin{array}{l}\text { Tetranychus } \\
\text { cinnabarinus }\end{array}$ & $\begin{array}{r}\text { RPS18 } \\
5.8 \mathrm{~S} \\
\text { rRNA }\end{array}$ & $\begin{array}{l}\text { RPS18 } \\
\alpha \text {-TUB }\end{array}$ & - & - & - & - & - & - & - & - \\
\hline $\begin{array}{l}\text { Bactrocera } \\
\text { minax }\end{array}$ & $\begin{array}{c}\text { TUB } \\
\text { GAPDH } \\
\text { GST }\end{array}$ & $\begin{array}{c}\text { UBQ } \\
\text { GAPDH } \\
\text { GST } \\
\alpha \text {-TUB }\end{array}$ & - & - & - & - & - & - & - & - \\
\hline $\begin{array}{l}\text { Bactrocera } \\
\operatorname{minax}\end{array}$ & - & $\begin{array}{l}\text { RPL32 } \\
\text { EF1- } \alpha\end{array}$ & - & - & - & - & - & - & - & - \\
\hline $\begin{array}{l}\text { Philosamia } \\
\text { Cynthia ricini }\end{array}$ & - & $\begin{array}{c}\text { RPS } \\
\text { GAPDH } \\
\alpha-T U B\end{array}$ & - & - & - & - & - & - & - & - \\
\hline $\begin{array}{l}\text { Aphis glycines } \\
\text { phyllonorycter }\end{array}$ & $\overline{\beta \text {-actin }}$ & $\begin{array}{c}\text { TBP } \\
\beta \text {-TUB }\end{array}$ & - & - & $\overline{\beta-a c t i n}$ & - & - & - & - & - \\
\hline Ringoniella & 18S rRNA & $\beta$-actin & - & - & $\beta$-TUB & - & - & - & - & - \\
\hline $\begin{array}{l}\text { Aphis gossypii } \\
\text { Glover }\end{array}$ & $\begin{array}{l}\text { PPI } \\
\text { DIMT }\end{array}$ & $\begin{array}{c}\text { PPI } \\
\text { RPII } \\
\text { DIMT }\end{array}$ & - & - & - & $\begin{array}{l}\text { PPI } \\
\text { DIMT }\end{array}$ & - & - & - & - \\
\hline P.solenopsis & - & $\alpha$-TUB & - & rpl32 & - & - & - & - & - & - \\
\hline Panonychus citri & - & RPII & - & $\begin{array}{c}\alpha \text {-TUB } \\
\text { RPII }\end{array}$ & $\begin{array}{l}\text { EF-1 } \alpha \\
\text { GAPDH }\end{array}$ & - & - & - & - & - \\
\hline $\begin{array}{l}\text { Nilaparvata } \\
\text { lugens }\end{array}$ & $\begin{array}{l}\text { RPL10 } \\
\text { AK } \\
\text { EF-1 } \alpha\end{array}$ & $\begin{array}{l}\text { GAPDH } \\
\text { UCCR }\end{array}$ & $\begin{array}{l}\text { RPL10 } \\
\text { EF-1 } \alpha\end{array}$ & $\begin{array}{l}\text { GAPDH } \\
\text { EF-1 } \alpha\end{array}$ & - & - & - & - & - & - \\
\hline Desert locust & $\begin{array}{c}\text { GAPDH } \\
\text { UBI } \\
\text { EF-1 } \alpha\end{array}$ & $\begin{array}{l}\text { RP49 } \\
\text { EF-1 } \alpha \\
\text { ACT } \\
\text { rps6 }\end{array}$ & - & - & - & - & - & - & - & - \\
\hline T. castaneum & - & $\begin{array}{c}\text { rpl13a } \\
\text { rps3 } \\
\text { rps18 } \\
\text { 18SrRNA } \\
\text { 28SrRNA }\end{array}$ & - & - & - & - & - & - & - & - \\
\hline Lucilia cuprina & - & $\begin{array}{c}\text { GST1 } \\
\beta-T U B \\
\text { RPLPO }\end{array}$ & - & - & - & - & - & - & - & - \\
\hline $\begin{array}{l}\text { Cimex } \\
\text { lectularius }\end{array}$ & RPL18 & RPL18 & - & - & - & - & - & - & - & - \\
\hline H. armigera & $\begin{array}{l}\text { RPS15 } \\
\text { RPL13 }\end{array}$ & $\begin{array}{l}\text { 28S rRNA } \\
\text { RPS15 }\end{array}$ & - & $\begin{array}{l}\text { RPS15 } \\
\text { RPL27 }\end{array}$ & $\begin{array}{l}\text { RPS15 } \\
\text { RPL32 }\end{array}$ & - & - & $\begin{array}{c}\text { GAPDH } \\
\text { RPL27 } \\
\beta \text {-TUB }\end{array}$ & - & - \\
\hline $\begin{array}{l}\text { Helicoverpa } \\
\text { armigera }\end{array}$ & - & $\begin{array}{l}\text { RPL28 } \\
\text { RPS15 } \\
\text { Actin }\end{array}$ & - & $\begin{array}{l}\text { RPL28 } \\
\text { RPS15 }\end{array}$ & - & - & $\begin{array}{l}\text { RPL28 } \\
\text { RPS15 }\end{array}$ & - & $\begin{array}{l}\text { HSP90 } \\
\text { TUBB }\end{array}$ & $\begin{array}{c}\text { TUBB } \\
\text { GAPDH }\end{array}$ \\
\hline Calliphoridae & - & $\begin{array}{l}\text { Gapdh } \\
\text { Rp49 }\end{array}$ & - & - & - & - & - & - & - & - \\
\hline Ae.albopictus & $\begin{array}{l}\text { rspL40 } \\
\text { BTF3a }\end{array}$ & - & - & - & - & $\begin{array}{l}\text { rspL40 } \\
\text { rsp5 }\end{array}$ & - & - & - & - \\
\hline B. dorsalis & a-TUB & - & - & - & - & - & - & - & - & - \\
\hline $\begin{array}{l}\text { Bombus } \\
\text { terrestris }\end{array}$ & $\begin{array}{c}\text { AK } \\
\text { PLA2 }\end{array}$ & - & - & - & - & - & - & - & - & - \\
\hline $\begin{array}{l}\text { Bombus } \\
\text { lucorum }\end{array}$ & $\begin{array}{l}\text { EF-1a } \\
\text { PLA2 }\end{array}$ & - & - & - & - & - & - & - & - & - \\
\hline A. planipennis & TEF- $1 \alpha$ & TEF- $1 \alpha$ & - & - & - & - & - & - & - & - \\
\hline $\begin{array}{l}\text { Drosophila } \\
\text { melanogaster }\end{array}$ & - & - & - & $\begin{array}{l}\text { Actin } \\
\text { Mnf } \\
\text { TUB }\end{array}$ & - & $\begin{array}{l}\text { RPL32 } \\
\alpha \text {-TUB }\end{array}$ & - & - & - & $\begin{array}{c}\text { ACT } \\
\text { TUB } \\
\text { EF-1 } \alpha\end{array}$ \\
\hline Honeybee & - & - & - & - & - & - & - & $\begin{array}{l}\text { RPS18 } \\
\text { GAPDH }\end{array}$ & - & - \\
\hline $\begin{array}{l}\text { Delphacodes } \\
\text { kuscheli }\end{array}$ & - & - & - & - & - & - & - & UBI & - & - \\
\hline
\end{tabular}




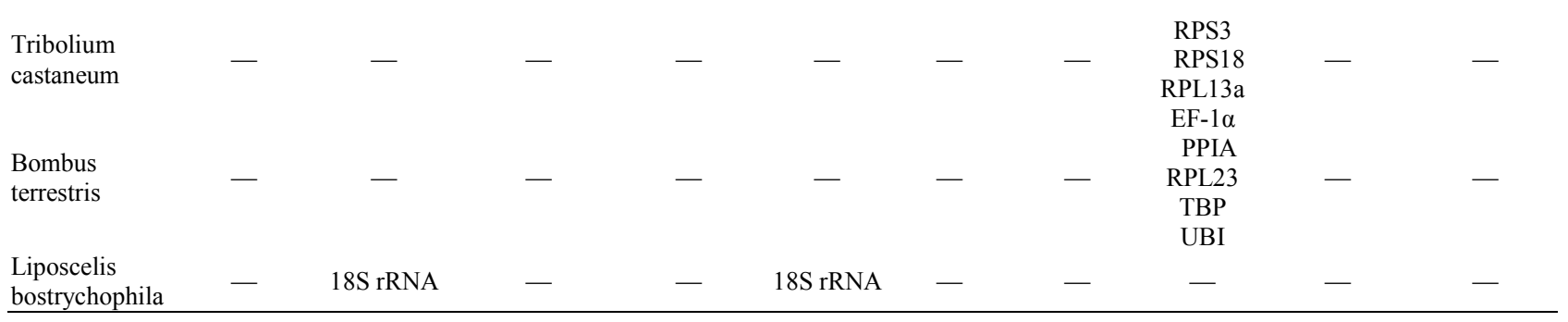

\section{Analysis of Reference Genes Expression Stability}

As the current, three freely available software tools, for example GeNorm[54], NormFinder[55], and BestKeeper [56], were usually comprehensively used to evaluate reference gene expression stability.

GeNorm program was compiled by Jo Vandesompele in 2002, was used to identify genes that were the most stably expressed for all of the experimental conditions. The program defines two parameters to quantify the housekeeping gene stability: $\mathrm{M}$ (the arithmetic mean of the pairwise variations between a particular gene and all other candidate control genes) and $\mathrm{V}$ (the pairwise variation).The least stable genes have the highest $M$ values and are successively excluded. Furthermore, To obtain the optimal number of reference genes for data normalization, we calculated the pairwise variation $(\mathrm{Vn} / \mathrm{n}+1)$ of serial log-transformed $\mathrm{NF}$ ratios using $\mathrm{N}$ relative to $\mathrm{N}+1$ reference genes as previously described. The $\mathrm{Vn} / \mathrm{n}+1$ value reflects NF stability across samples. While individual reference genes have considerably differential expression levels across samples, NF will be sensitive to stepwise inclusion of these reference genes resulting in an increase or decrease in $\mathrm{Vn} / \mathrm{n}+1$ value. If inclusion of more or less reference genes has little or no effect on $\mathrm{Vn} / \mathrm{n}+1$ value, NF will become insensitive to stepwise inclusion of these reference genes and approach a relatively stable status with a minimal $\mathrm{Vn} / \mathrm{n}+1$ value, which was below the default cut-off value of $\mathrm{V}=$ 0.15.GeNorm address: http://medgen.ugent.be/ jvdesomp/genorm/index.php

NormFinder program was compiled by Claus in 2004, applies a model-based approach, which in contrast to geNorm allows the assignment of groups to the samples (treatment vs. control). NormFinder approach attempts to compensate for expression differences between treatment and control by selecting combinations of genes with opposite expression and as little intra- and intergroup variation as possible. Inter- and intragroup variations are used for the calculation of a stability value i.e., candidates with minimal combined intra- and intergroup variation are ranked as the most stable genes. This approach has advantages over the pairwise comparison approach of geNorm if coregulated genes, but only selects one gene as optimal reference genes[57]. NormFinder address:

http://www.mdl.dk/publicationsnormfinder.htm

BestKeeper Excel tool was compiled by Pfaffl in 2004, analyzes each gene's expression variability by calculating the Ct set standard deviation (SD) and coefficient of variance (CV) and then by pair-wise comparison calculates the correlation between the genes and with the Bestkeeper index. The most stable genes have the lowest $\mathrm{CV}$ values. BestKeeper address: http://www.gene-quantification.de/bes t-keeper.html

\section{Conclusions}

On the basis of the research results of the insects internal reference genes in domestic and foreign, have shown that the optimum internal reference genes is not identical among different tissue, organ types, physiological conditions, or species, can't be used directly before don't be tested and verified. In addition, the different internal reference genes of the same species or dealing factors also are related with the selection of candidate housekeeping genes.

For reliable results, must select the appropriate internal reference genes to deter error such as inaccurate quantification of RNA, the quality of the RNA, and difference during cDNA synthesis that can trigger variations in PCR reactions[58,59]. From the existing reports, the optimum internal reference genes is not identical in different species or dealing factors $[60,61,62]$. For example, ACT was used commonly as internal reference gene for researching the whiteflies[63,64],but $\mathrm{Su}$ [7] had shown that ACT is not stable in many conditions. Therefore, can't blindly select internal reference genes. Internal reference genes are stable expression only in certain types of cells, or specific experimental factors. It will be more several times or even one hundred times differences if select improper Internal reference genes[65,66]. At the same time, it is best to use two or more internal reference genes to adjust the system deviation, especially outstanding in genetic subtle expression.

\section{REFERENCES}

[1] Nolan T, Hands RE, Bustin SA,2006. Quantification of mRNA using real-time RT-PCR[J]. Nat. protoc., 1:1559-1582.

[2] Butin SA. 2010. why the need for qPCR publication guidelines?-The case for MIQE[J]. Methods ,50: 217-226. 
[3] Taylor S, Wakem M, Dijkman G,et al.2010. A practical approach to RT-qPCR-Publishing data that conform to the MIQE guidelines[J]. Methods ,50:S1-5.

[4] Peters IR, Helps CR, Hall EJ,et al.2004. Real-time RT-PCR Considerations for efficient and sensitive assay design[J]. J. Immunol. Methods, 286:203-217.

[5] Suzuki T, Higgins PJ, Crawford DR.2000. Control selection for RNA quantitation[J]. Biotechniques, 29(2):332-337.

[6] Coulson DT, Brockbank S, Quinn JG, et al.2008. Identification of valid reference genes for the normalization of RT qPCR gene expression data in human brain tissue[J]. BMC Mol Biol ,9:46.

[7] $\mathrm{Su} \mathrm{YL,} \mathrm{He} \mathrm{WB,} \mathrm{Wang} \mathrm{J,et} \mathrm{al.} \mathrm{2013.} \mathrm{Selection} \mathrm{of} \mathrm{endogenous}$ reference genes for gene expression analysis in the Mediterranean species of the whitefly Bemisia tabaci (Hemiptera: Aleyrodidae) complex[J]. Journal of Economic Entomology, 106(3):1446-1455.

[8] Yuan M, Lu Y, Zhu X, et al. 2014. Selection and evaluation of potential reference genes for gene expression analysis in the brown planthopper, Nilaparvata lugens (Hemiptera: Delphacidae) using reverse-transcription quantitative PCR[J]. PLoS ONE, 9(1):e86503.

[9] Huggett J, Dheda K, Bustin S,et al.2005. Real-time RT-PCR normalization; strategies and considerations[J]. Genes Immun, 6:279-284.

[10] Gutierrez L, Mauriat M, Guenin S, et al.2008. The lack of a systematic validation of reference genes: a serious pitfall undervalued in reverse transcription-polymerase chain reaction(RT-PCR) analysis in plants[J]. Plant Biotechnol J, 6:609-618.

[11] Pei Liang, Yajie Guo, Xuguo Zhou, et al. Expression profiling in Bemisia tabaci under insecticide treatment: indicating the necessity for custom reference gene selection[J].PLOSONE,2014,doi:10.1371/journal.pone.0087 514.

[12] Bustin SA. 2002. Quantification of mRNA using real-time reverse transcription PCR(RT-PCR): trends and problems $[\mathrm{J}]$. J Mol Endocrinol ,29(1):17.

[13] Wan HJ, Zhao ZG, Qian CT, et al.2010.Selection of appropriate reference genes for gene expression studies by quantitative real-time polymerase chain reaction in cucumber[J]. Analytical Biochemistry,399(2):257-261.

[14] Lilly ST, Drummond RSM, Pearson MN, et al. 2011. Identification and validation of reference genes for normalization of transcripts from virus-infected Arabidopsis thaliana[J]. Molecular Plant Microbe Interactions, 24(3):294-304.

[15] Sekalska B, Ciechanowiez A, Dolegowska B,et al. 2006. Optimized RT-PCR method for assaying expression of monocyte chemotactic protein type $1(\mathrm{MCP}-1)$ in rabbit aorta[J]. Biochem Genet,44(3):133-143.

[16] Li-hua Chen,Yue-hua Zhang,Qing-ling He,et al. 2014. Selection of reference genes for transcription expression analysis in Philosamia Cynthia ricini[J].Journal of agricultural university of hebei, 37(6):78-84.

[17] Miao Yuan.2014.Selection of Potential Reference Genes in Nilaparvata lugens and the Molecular Characterization of
Arginine Kinase Gene [D].Wu han: Huazhong Agricultural University, 50-54.

[18] W Sun, Y Jin, L He,et al. 2010. Suitable reference gene selection for different strains and developmental stages of the carmine spider mite, Tetranychus cinnabarinus, using quantitative real-time PCR[J]. Journal of Insect Science, 10(208):1-12.

[19] Jia Wang, Jing Zhao, Ying-hong Liu. 2014. Evaluation of endogenous reference genes in Bactrocera minax (Diptera: Tephritidae)[J].Acta Entomologica Sinica,57(12):1375-1380.

[20] Lü ZC, Wang LH, Dai RL, et al. 2014.Evaluation of endogenous reference genes of Bactrocera (Tetradacus) minax by gene expression profiling under various experimental conditions $[\mathrm{J}]$. Florida Entomologist, 97(2):597-604.

[21] Liu-hao Wang. 2013.The transcriptome sequencing and diapause related gene-cloning research of Bactrocera Minax[D].Henan Institute of Science and Technology, 53-59

[22] Wang Song,Xiao-ji Wang,Rui-jian Guo,et al. 2015.Selection of Reference Genes for Quantitative Real-time PCR Normalization in Dastarcus helophoroides[J].Acta Agriculturae Boreali-occidentalis Sinica, 24(2):156-161.

[23] Raman Bansal, Praveen Mamidala, M. A.Rouf Mian, et al. 2012. Validation of reference genes for gene expression studies in aphis glycines[J]. Entomological Society of America, 105(4):1432-1438.

[24] Chang-ning Guo.2014.Cloning and stability analysis of reference gene from Phyllonorycter Ringoniella [D].Shanxi:Northwest A \& F University,32-49.

[25] Su-ping Xu.2014.Cloning and expression analysis of odorant binding proteins in Aphis Gossypii Glover[D].Wuhan: Huazhong Agricultural University, 35-47.

[26] Fang Chen,Yong-yue Lu.2014.Selection of reference genes in Phenacoccus solenopsis (Hemiptera: Pseudococcidae) under heat stress [J].Acta Entomologica Sinica, 57(10):1146- 1154.

[27] JZ Niu, W Dou, TB Ding, et al.2012. Evaluation of suitable reference genes for quantitative RT-PCR during development and abiotic stress in Panonychus citri (McGregor)(Acari: Tetranychidae) [J].Molecular biology,39(5):5841-5849.

[28] Lu Y, Yuan M, Gao X, et al. 2013. Identification and validation of reference genes for gene expression analysis using quantitative PCR in Spodoptera litura (Lepidoptera: Noctuidae) [J].PloS ONE, 8(7):e68059.

[29] Matthias B Van Hiel, Pieter Van Wielendaele, Liesbet Temmerman, et al. 2009.Identification and validation of housekeeping genes in brains of the desert locust Schistocerca gregaria under different developmental conditions[J]. BMC Molecular Biology, 10:56.

[30] MICHELLE J. TOUTGES,KRIS HARTZER, JEFFREY LORD,et al. 2010. Evaluation of Reference Genes for Quantitative Polymerase Chain Reaction across Life Cycle Stages and Tissue Types of Tribolium castaneum[J]. J. Agric. Food Chem. 58, 8948-8951.

[31] N.H.BAGNALL, A.C.KOTZE. 2010.Evaluation of reference genes for real-time PCR quantification of gene expression in the Australian sheep blowfly, Lucilia cuprina[J]. Medical and Veterinary Entomology ,24, 176-181. 
[32] PRAVEEN MAMIDALA, SWAPNA P. RAJARAPU, SUSAN C. JONES,et al. 2011. Identification and Validation of Reference Genes for Quantitative Real-Time Polymerase Chain Reaction in Cimex lectularius[J]. Journal of Medical Entomology, 48(4):947-951.

[33] Songdou Zhang, Shiheng An, Zhen Li, et al. 2015 . Identification and validation of reference genes for normalization of gene expression analysis using qRT-PCR in Helicoverpa armigera (Lepidoptera: Noctuidae) [J]. Gene, 555:393-402.

[34] Muhammad Shakeel, Xun Zhu, Tinghao Kang, et al. 2015.Selection and evaluation of reference genes for quantitative gene expression studies in cotton bollworm, Helicoverpa armigera(Lepidoptera: Noctuidae) [J]. Journal of Asia-Pacific Entomology, 18:123-130.

[35] Gisele Antoniazzi Cardoso, Cleverson Carlos Matiolli, Ana Maria Lima de AzeredoEspin,et al. 2014.Selection and validation of reference genes for functional studies in the Calliphoridae family[J]. Journal of Insect Science, 14:2

[36] Jia-hong Wu,Jing-zhing Chen, Yu Sun,et al. 2011.Selection of control genes in Real-time qPCR analysis of gene expression in Aedes albopictus [J].Chinese Journal of Zoonoses, 27(5):432-435.

[37] Ran Peng. 2012.Analysis of reference gene expression for real time PCR based on relative quantitative and dual spike-in strategy in the silkworm Bombyx mori [D].Suzhou:Soochow University, 19-33.

[38] Shen G M, Jiang H B, Wang X N, et al. 2010.Evaluation of endogenous references for gene expression profiling in different tussues of the oriental fruit fly Bactrocera dorsalis(Diptera: Tephritidae)[J]. BMC Molecular Biology, 11:76.

[39] Yu Wu,Yuan-fen Zhai, Ming-xia Huang, et al.2013.The expression stability analysis of commonly used reference genes and research on the expression regulation of silk protein related genes in Bombyx mori[J]. Chinese Journal of Cell Biology, 35(4):423-431.

[40] Rafaela M Paim, Marcos H Pereira, Raffaello Di Ponzio,et al. 2012.Validation of reference genes for expression analysis in the salivary gland and the intestine of Rhodnius prolixus (Hemiptera: Reduviidae) under different experimental conditions by quantitative real-time PCR[J]. BMC Research Notes, 5:128.

[41] D. Majerowicz, M. Alves-Bezerra, R. Logullo†, et al. 2011.Looking for reference genes for real-time quantitative PCR experiments in Rhodnius prolixus (Hemiptera: Reduviidae) [J]. Insect Molecular Biology, 20(6):713-722.

[42] Darina Hornakova , Petra Matouškova , Jiři Kindl,et al 2010.Selection of reference genes for real-time polymerase chain reaction analysis in tissues from Bombus terrestris and Bombus lucorum of different ages[J]. Analytical Biochemistry, 397,118-120.

[43] Swapna Priya Rajarapu, Praveen Mamidala, Omprakash Mittapalli,et al. 2012.Validation of reference genes for gene expression studies in the emerald ash borer (Agrilus planipennis) [J]. Insect Science, 19,41-46.

[44] Fleur Ponton, Marie-Pierre Chapuis, Mathieu Pernice, et al. 2011.Evaluation of potential reference genes for reverse transcription-qPCR studies of physiological responses in
Drosophila melanogaster[J]. Journal of Insect Physiology, (57):840-850

[45] Scharlaken B, de Graaf D C, Goossens K, et al . 2008. Reference gene selection for insect expression studies using quantitative real-time PCR: The head of the honeybee, apis mellifera, after a bacterial challenge[J]. Journal of Insect science, $8: 33$.

[46] Guillermo A Maroniche, Mónica Sagadín, Vanesa C Mongelli,et al. 2011.Reference gene selection for gene expression studies using RT-qPCR in virus-infected planthoppers[J]. Virology Journal, 8:308

[47] Jian-Li Xue, Tamer Z. Salem, Colin M. Turney,et al. 2010.Strategy of the use of 28S rRNA as a housekeeping gene in real-time quantitative PCR analysis of gene transcription in insect cells infected by viruses[J]. Journal of Virological Methods, 163:210-215.

[48] Jeffrey C. Lord, Kris Hartzer, Michelle Toutges,et al. 2010.Evaluation of quantitative PCR reference genes for gene expression studies in Tribolium castaneum after fungal challenge[J]. Journal of Microbiological Methods, 80:219-221.

[49] Jinzhi Niu, Kaat Cappelle, Joachim R.de Miranda, et al. 2014.Analysis of reference gene stability after Israeli acute paralysis virus infection in bumblebees Bombus terrestris[J]. Journal of Invertebrate Pathology, 115:76-79.

[50] Hong-Bo Jiang, Yong-Hua Liu, Pei-An Tang, et al. 2010.Validation of endogenous reference genes for insecticide-induced and developmental expression profiling of Liposcelis bostsrychophila (Psocoptera: Liposcelididae) [J]. Mol Biol Rep , 37:1019-1029.

[51] KI Spanier, F Leese, C Mayer, et al. 2010. Predator-induced defences in Daphnia pulex: Selection and evaluation of internal reference genes for gene expression studies with real-time PCR[J]. BMC Molecular Biology, 11:50.

[52] Marie-Pierre Chapuis, Donya Tohidi-Esfahani, Tim Dodgson,et al. 2011.Assessment and validation of a suite of reverse transcription quantitative PCR reference genes for analyses of density-dependent behavioural plasticity in the Australian plague locust[J]. BMC Molecular Biology, 12:7.

[53] Yu Wang, Zhong-Kang Wang, Yi Huang, et al. 2014.Identification of suitable reference genes for gene expression studies by qRT-PCR in the blister beetle Mylabris cichorii[J]. Journal of Insect Science, 14:94.

[54] Vandesompele J, De Preter K, Pattyn F, et al. 2002.Accurate normalization of real-time quantitativeRT-PCR data by geometric averaging of multiple internal control genes [J]. Genome Biol, 3:RESEARCH0034.

[55] Andersen C,Ledet-Jensen J, Orntoft T. 2004.Normalization of real-time quantitative RT-PCR data: a model-based variance estimation approach to identify genes suited for normalization, applied to bladder and colon cancer data sets [J]. Cancer Res. 64: 5245-5250.

[56] Pfaffl M, Tichopad A, Prgomet C, et al. 2004. Determination of stable housekeeping genes, differentially regulated target genes and sample integrity: BestKeeper-Excel-based tool using pair-wise correlations [J]. Biotechnol Lett, 26: 509-515.

[57] Ferreira E, Cronjé MJ.2012. Selection of suitable reference genes for quantitative real-time PCR in apoptosis-induced 
MCF-7 breast cancer cells[J]. Mol Biotechnol, 50: 121-128

[58] Massimo bionaz, Juan J L. 2007. Identification of reference genes for quantitative real-time PCR in the bovine mammary gland during the lactation cycle[J]. Physiol Genomics, 29:312-319.

[59] Ponton F, Chapuis M P, Pernice M, et al. 2011.Evaluation of potential reference genes for reverse transcription qPCR studies of physiological responses in Drosophila melanogaster[J]. J Insect Physiol, 57:840-850.

[60] Thais Barros Rodrigues, Chitvan Khajuria, Haichuan Wang, et al.Validation of reference housekeeping genes for gene expression studies in Western corn rootworm(Diabrotica virgifera

virgefera)[J].PLOSONE,2014,doi:10.1371/journal.pone.010 9825.

[61] Guoying Han, Xiumin Li, Ting Zhang, et al.Cloning and tissue-specific expression of a chitin deacetylase gene from Helicoverpa armigera (Lepidoptera: Noctuidae) and its response to Bacillus thuringiensis[J]. Journal of Insect Science,2015,15(1):doi:10.1093/jisesa/iev076.
[62] Yu-Tao Zheng, Hong-Bo Li, Ming-Xing Lu, et al. Evaluation and validation of reference genes for qRT-PCR normalization in Frankliniella occidentalis (Thysanoptera:Thripidae )[J]. PLOSONE,2014,doi:10.1371/journal.pone.0111369.

[63] $\mathrm{Li} \mathrm{JM}, \mathrm{Su} \mathrm{YL}, \mathrm{Gao} \mathrm{XL}$, et al. 2011.Molecular characterization and oxidative stress response of an intracellular $\mathrm{Cu} / \mathrm{Zn}$ superoxide dismutase $(\mathrm{Cu} / \mathrm{Zn} \mathrm{SOD})$ of the whitefly, Bemisia tabaci[J]. Archives of Insect Biochemistry and Physiology, 77(3):118-133.

[64] Luan JB, Li JM, Varela N, et al. 2011. Global analysis of the transcriptional response of whitefly to tomato yellow leaf curl China virus reveals the relationship of coevolved adaptations[J]. Journal of Virology, 85(7):3330-3340.

[65] Hayati MI, Robert S, Rosanme E, et al. 2004.Comparison of reference genes for quantitative real-time polymerase chain reaction analysis of gene expression in sugarcane[J]. Plant Molecular Biology reporter, 22:325-337.

[66] Liu D W, Chen S T, Liu H P. 2005.Choice of endogenous control for gene expression in nonsmall cell lung cancer[J]. Eur Respir J, 26 (6): 1002-1008. 